\title{
COVID-19 in pregnancy: What do we really know? [version 1;
}

\section{peer review: 1 approved, 1 approved with reservations]}

\author{
Jerome Bouaziz1,2, Marc Even 1,2, Frederique Isnard-Bogillot ${ }^{1}$, Eli Vesale1, \\ Mariam Nikpayam¹, Andrei Mihalache1', David Krief1, Rene Frydman², \\ Jean-March Ayoubi²
}

${ }^{1}$ Pointgyn Research Department Unit, Plaisir, 78370, France

${ }^{2}$ Department of Gynecology, Foch Hospital, Suresnes, France

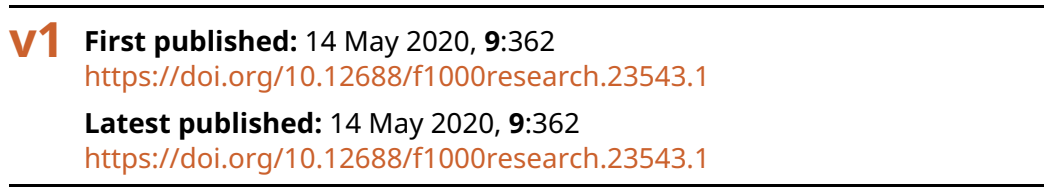

\section{Abstract}

Coronavirus disease 2019 (COVID-19) pandemic, caused by severe acute respiratory syndrome coronavirus 2 (SARS-CoV-2), continues to escalate worldwide and has become a pressing global health concern. This article comprehensively reviews the current knowledge on the impact of COVID-19 over pregnant women and neonates, as well as current recommendations for their management. We also analyse previous evidences from viral respiratory diseases such as SARS, Middle East respiratory syndrome, and influenza that may help to guide clinical practice during the current pandemic. We collected 23 case reports, case series, and case-control studies (18 from China) comprising 174 pregnant women with COVID-19. The majority of mothers showed a clinical presentation of the disease similar to that of non-infected adults. Preliminary evidences point towards a potentially increased risk of pregnancy adverse outcomes in women with COVID-19, with preterm delivery the most frequently observed (16.7\%) followed by fetal distress $(9.77 \%)$. The most commonly reported adverse neonatal outcomes included respiratory symptoms (7.95\%) and low birth weight (6.81\%). A few studies reported other maternal comorbidities that can influence these outcomes. Mothers with other comorbidities may be at higher risk of infection. Mother-tochild transmission of SARS-CoV-2 appears unlikely, with no study observing intrauterine transmission, and a few cases of neonatal infection reported a few hours after birth. Although the WHO and other health authorities have published interim recommendations for care and management of pregnant women and infants during COVID19 pandemic, many questions remain open. Pregnant women should be considered in prevention and control efforts, including the development of drugs and vaccines against SARS-CoV-2. Further research is needed to confirm the exact impact of COVID-19 infection during pregnancy. To fully quantify this impact, we urgently need to integrate the current knowledge about viral characteristics,

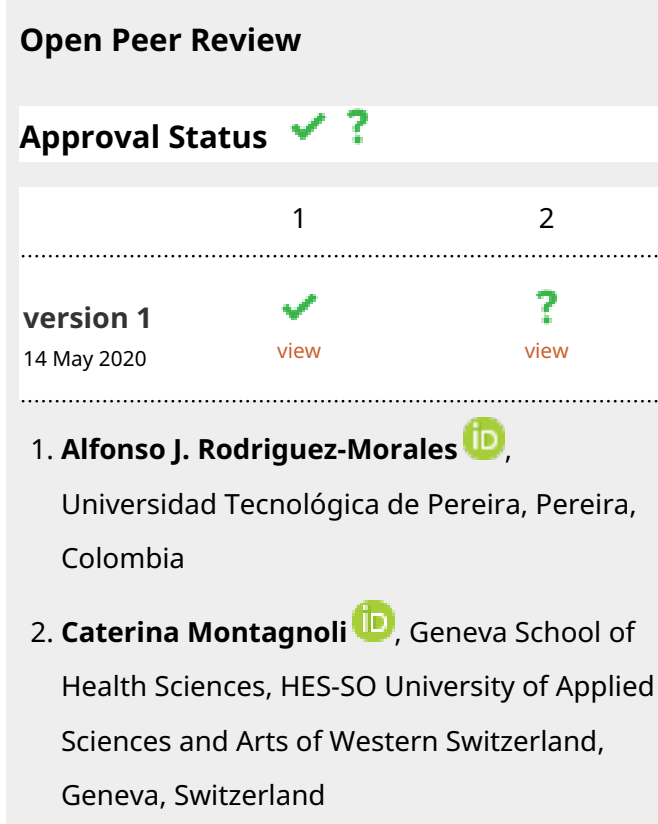

Any reports and responses or comments on the article can be found at the end of the article. 
epidemiology, disease immunopathology, and potential therapeutic strategies with data from the clinical practice.

\section{Keywords}

coronavirus disease, covid, infection, pregnancy, neonate, outcomes, vertical transmission

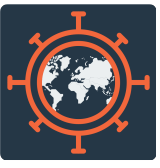

This article is included in the Emerging Diseases and Outbreaks gateway.

\section{8:}

This article is included in the Coronavirus

collection.

\section{Corresponding author: Jerome Bouaziz (dr.jeromebouaziz@pointgyn.com)}

Author roles: Bouaziz J: Conceptualization, Data Curation, Formal Analysis, Investigation, Methodology, Project Administration, Validation, Writing - Original Draft Preparation, Writing - Review \& Editing; Even M: Resources, Supervision, Writing - Original Draft Preparation, Writing - Review \& Editing; Isnard-Bogillot F: Formal Analysis, Resources, Writing - Original Draft Preparation, Writing Review \& Editing; Vesale E: Validation, Writing - Review \& Editing; Nikpayam M: Conceptualization, Data Curation, Investigation, Supervision, Writing - Original Draft Preparation; Mihalache A: Funding Acquisition, Investigation, Resources, Validation, Visualization, Writing - Original Draft Preparation, Writing - Review \& Editing; Krief D: Methodology, Project Administration, Resources, Software, Validation; Frydman R: Validation, Writing - Original Draft Preparation, Writing - Review \& Editing; Ayoubi JM: Formal Analysis, Writing Original Draft Preparation, Writing - Review \& Editing

Competing interests: No competing interests were disclosed.

Grant information: The author(s) declared that no grants were involved in supporting this work.

Copyright: (c) 2020 Bouaziz J et al. This is an open access article distributed under the terms of the Creative Commons Attribution License , which permits unrestricted use, distribution, and reproduction in any medium, provided the original work is properly cited.

How to cite this article: Bouaziz J, Even M, Isnard-Bogillot $F$ et al. COVID-19 in pregnancy: What do we really know? [version 1; peer review: 1 approved, 1 approved with reservations] F1000Research 2020, 9:362 https://doi.org/10.12688/f1000research.23543.1

First published: 14 May 2020, 9:362 https://doi.org/10.12688/f1000research.23543.1 


\section{Introduction}

Coronavirus disease 2019 (COVID-19) has emerged as the most pressing current global health issue. Since the identification of the first cases of severe acute respiratory syndrome coronavirus 2 (SARS-CoV-2) infection causing COVID-2019 in Wuhan, China, in December $2019^{1}$, the virus has spread almost to every country in the world. Local transmission of SARS-CoV-2 is occurring in most countries ${ }^{2}$. The World Health Organization (WHO) declared COVID-19 a "public health emergency of international concern' on 30th January 2020, and characterized the situation as pandemic on 11th March 2020. According to WHO situation report from 7th April 2020, there were around 1,280,000 COVID-19 confirmed cases and over 72,600 deaths worldwide, with Europe and North America being the current epicentres of the pandemic ${ }^{2}$. The numbers continue to grow at staggering speed.

SARS-CoV-2 is the seventh known coronavirus that infects humans, and several studies support its probable zoonotic origin ${ }^{3,4}$. SARS-CoV-2 belongs to the betacoronaviridae and, similarly to other members of this genus such as severe acute respiratory syndrome coronavirus (SARS-CoV), binds to angiotensinconverting enzyme 2 (ACE2) as the host receptor for entering the cell to cause infection ${ }^{5,6}$. Although current data suggest that the majority of infections with SARS-CoV-2 cause a mild presentation of COVID-19, older adults and people with comorbidities, including cardiovascular and respiratory diseases and diabetes, are at increased risk of severity and death, with men potentially at higher risk than women ${ }^{7,8}$.

Pregnant women are particularly vulnerable to infectious diseases that can cause both maternal and fetal adverse outcomes, compared to their non-pregnant counterparts. Infections caused by influenza virus ${ }^{9,10}$, hepatitis $\mathrm{E}$ virus ${ }^{11}$, herpes simplex virus ${ }^{12}$, cytomegalovirus $^{12}$, human papilloma virus ${ }^{13}$, and malaria parasites $^{14}$, among others, more severely affect women during gestation. During pregnancy, women experience a series of immunological transformations that allow the immune system to tollerate and support the growing fetus while still maintaining antimicrobial defence and tissue repair ${ }^{15}$. These transformations, together with mechanical or anatomical changes, may explain the increased severity or susceptibility to some infectious diseases observed in pregnant women ${ }^{16}$.

In particular, the physiological and immunological changes associated with gestation make pregnant women at increased risk for serious viral respiratory illness ${ }^{17}$. In view of the urgent threat that COVID-19 pandemic is posing worldwide, obstetricians and future mothers are wondering whether SARS-CoV-2 infection could be associated with adverse fetal and maternal outcomes and/or be transmitted to the fetus. Although current evidences are scarce, several case reports, case series, and case-control studies have already been published reporting clinical manifestations and evaluating the possibility of vertical transmission, as well as maternal and fetal outcomes in pregnant women with COVID-19.
This review collects up-to-date information from the existing literature about the presentation and outcomes of COVID-19 in pregnant women; and discusses current recommendations for their care and management. Moreover, since current knowledge about COVID-19 in pregnancy is scarce, we summarize previous evidences from the impact of other viral respiratory infections, including SARS-CoV, Middle East respiratory syndrome coronavirus (MERS-CoV), and influenza virus on maternal and fetal outcomes to get insights that may help to better understand COVID-19 and guide the clinical practice. We also discuss challenges that pregnant women may face in the context of the pandemic, including the access to safe therapeutic strategies and mental health issues, and the particularly difficult situation of those in low-resource settings.

The scientific community is intensively working to elucidate the impact of this global health concern over pregnant mothers and their newborns, but still many questions remain unanswered. Since new data are being collected everyday, it is essential to provide healthcare workers with the most updated information about COVID-19 in pregnant women. This information will help to answer the numerous questions that future mothers may have in the current situation and to prevent obstetrical complications.

\section{Methods}

After defining the research questions and objectives, we conducted a literature review using PubMed and Google Scholar. A first search was conducted on 27th March 2020, and a second search was conducted on 8th April 2020 to include the most recently published articles. We searched for articles including the terms 'COVID-19', 'SARS-CoV-2' or 'ncov-2019', and 'pregnancy', 'pregnant', 'gestation', 'newborn', 'neonatal', 'neonate' or 'perinatal' without limits. On 8th April 2020, this search produced 104 results. All abstracts were screened and relevant articles were further inspected. The bibliographic reference lists of the included articles were screened for additional publications. In total, 23 studies comprising case reports, case series, and case-control studies (reporting a total of 174 pregnant women with COVID-19) were included. Relevant information was extracted from the full-text articles, with the exception of one case series and one case-control study that were originally published in Mandarin Chinese (relevant data were extracted from the published English version of the abstract). Publications in Chinese without an English version of the abstract available were discarded. We also reviewed letters, perspectives, and reviews to obtain additional information. We searched for information about COVID-19, SARS-CoV-2, and other viral diseases in pregnancy in PubMed database and WHO webpage.

What do we know about COVID-19 in pregnancy?

This section reviews the reported cases of pregnant women with COVID-19 since the beginning of the pandemic until 8th April 2020 (summarized in Table 1 and Table 2). 


\section{Table 1. Summary of reported cases of coronavirus disease 2019 (COVID-2019) in pregnant women.}

\begin{tabular}{|c|c|c|c|c|c|}
\hline Reference & Country & $\begin{array}{l}\text { Infected } \\
\text { pregnant } \\
\text { women, } n\end{array}$ & Mode of delivery (n) & $\begin{array}{c}\text { Vertical } \\
\text { transmission }\end{array}$ & $\begin{array}{c}\text { Adverse pregnancy/neonatal } \\
\text { outcomes (n) }\end{array}$ \\
\hline Liu et al. ${ }^{18}$ & China & $\begin{array}{l}15 \text { ( } 4 \text { still } \\
\text { pregnant at } \\
\text { the end of the } \\
\text { study period) }\end{array}$ & $\begin{array}{l}\text { - Caesarean section (10) } \\
\text { - Vaginal delivery (1) } \\
\text { - Unknown (4, discharged } \\
\text { before delivery) }\end{array}$ & No & Not reported \\
\hline Chen et al. ${ }^{19}$ & China & 3 & $\begin{array}{l}\text { Emergency caesarean section } \\
\qquad(3)\end{array}$ & No & $\begin{array}{c}\text { - Preterm delivery (1) } \\
\text { - LBW (1) }\end{array}$ \\
\hline Chen et al. ${ }^{20}$ & China & 5 & $\begin{array}{l}\text { - Vaginal delivery (3) } \\
\text { - Caesarean section ( } 2 ; 1 \\
\text { emergency due to due to fetal } \\
\text { tachycardia, } 1 \text { elective due to } \\
\text { gestational diabetes) }\end{array}$ & No & Fetal tachycardia (1) \\
\hline Wang et al. ${ }^{21}$ & China & 1 & $\begin{array}{l}\text { Emergency caesarean section } \\
\text { (1) }\end{array}$ & No & $\begin{array}{c}\text { - Preterm delivery (1) } \\
\text { - LBW (1) }\end{array}$ \\
\hline Liu et al.22 & China & 13 & $\begin{array}{c}\text { - Caesarean section (10, of } \\
\text { which } 5 \text { were emergency) } \\
\text { - Unknown ( } 3 \text {, discharged } \\
\text { before delivery) }\end{array}$ & No & $\begin{array}{l}\text { - Maternal MODS including ARDS, } \\
\text { acute hepatic and renal failure, and } \\
\text { septic shock (1) } \\
\text { - Preterm delivery (6) } \\
\text { - Fetal distress (3) } \\
\text { - PROM (1) } \\
\text { - Stillbirth (1) }\end{array}$ \\
\hline Chen et al..$^{23}$ & China & 9 & Caesarean section (9) & No & $\begin{array}{l}\text { - Preterm delivery (4) } \\
\text { - PROM (2) } \\
\text { - Fetal distress (2) } \\
\text { - LBW (2) }\end{array}$ \\
\hline Chen et al..$^{24}$ & China & 17 & $\begin{array}{c}\text { Caesarean section (14 } \\
\text { epidural anesthesia, } 3 \text { general } \\
\text { anesthesia) }\end{array}$ & No & $\begin{array}{c}\text { - Intraoperative hypotension in } \\
\text { women undergoing epidural } \\
\text { anesthesia (12) } \\
\text { - Preterm delivery (3) }\end{array}$ \\
\hline Zhang et al. ${ }^{25}$ & China & 1 & $\begin{array}{l}\text { Emergency caesarean section } \\
\text { (1) }\end{array}$ & Not reported & $\begin{array}{c}\text { - Maternal severe ARDS, multiple } \\
\text { organ dysfunction syndrome, and } \\
\text { septic shock (1) } \\
\text { - Fetal death (endouterine } \\
\text { asphyxia) (1) }\end{array}$ \\
\hline Zhu et al. ${ }^{26}$ & China & 9 & $\begin{array}{l}\text { - Caesarean section (7) } \\
\text { - Vaginal delivery (2) }\end{array}$ & No & $\begin{array}{c}\text { - Fetal distress (6) } \\
\text { - Preterm delivery (6) } \\
\text { - SGA (2) } \\
\text { - PCIS<90 (6) } \\
\text { - Shortness of breath (6) } \\
\text { - Fever (2) } \\
\text { - Thrombopenia accompanied by } \\
\text { abnormal liver function (2) } \\
\text { - Rapid heart rate (1) } \\
\text { - Vomiting (1) } \\
\text { - Pneumothorax (1) } \\
\text { - Infant death (1) }\end{array}$ \\
\hline Fan et al. ${ }^{27}$ & China & 2 & Caesarean section (2) & No & $\begin{array}{c}\text { - Lymphopenia (2) } \\
\text { - Low-grade fever (1) } \\
\text { - Mild neonatal pneumonia (1) } \\
\text { - Diffuse haziness in both lung } \\
\text { fields without patchy consolidation } \\
\text { (1) }\end{array}$ \\
\hline Yu et al..$^{28}$ & China & 7 & Caesarean section (7) & $\begin{array}{l}\text { ? }(1 \text { neonate } \\
\text { positive } 36 \mathrm{~h} \\
\text { after birth) }\end{array}$ & Not reported \\
\hline Li et al. ${ }^{29}$ & China & 1 & $\begin{array}{l}\text { Emergency caesarean section } \\
\qquad(1)\end{array}$ & No & Preterm delivery (1) \\
\hline Xia et al..$^{30}$ & China & 1 & $\begin{array}{l}\text { Emergency caesarean section } \\
\text { (1) }\end{array}$ & No & Not reported \\
\hline
\end{tabular}




\begin{tabular}{|c|c|c|c|c|c|}
\hline Reference & Country & $\begin{array}{l}\text { Infected } \\
\text { pregnant } \\
\text { women, } n\end{array}$ & Mode of delivery (n) & $\begin{array}{l}\text { Vertical } \\
\text { transmission }\end{array}$ & $\begin{array}{c}\text { Adverse pregnancy/neonatal } \\
\text { outcomes (n) }\end{array}$ \\
\hline Wang et al. ${ }^{31}$ & China & 1 & $\begin{array}{c}\text { Emergency caesarean section } \\
\text { (1) }\end{array}$ & $\begin{array}{l}\text { ? (1 neonate } \\
\text { positive } 36 \mathrm{~h} \\
\text { after birth) }\end{array}$ & Neonatal swallowing syndrome (1) \\
\hline Zeng et al.32 & China & 33 & Caesarean section (33) & $\begin{array}{l}\text { ? ( } 3 \text { neonates } \\
\text { positive on day } \\
2 \text { after birth) }\end{array}$ & $\begin{array}{c}\text { - Shortness of breath (4) } \\
\text { Positive neonates at day 2: } \\
\text { - Pneumonia (3) } \\
\text { - Fever (2) } \\
\text { - Lethargy (2) } \\
\text { - Respiratory distress syndrome (1) } \\
\text { - Leukocytosis (1) } \\
\text { - Lymphopenia (1) } \\
\text { - Elevated CK-MB fraction (1) } \\
\text { - Bacterial sepsis (1) }\end{array}$ \\
\hline Dong et $a l^{33}$ & China & 1 & Caesarean section (1) & $\begin{array}{l}\text { ? (neonate } \\
\text { positive for } \\
\text { SARS-CoV-2 } \\
\text { IgG and IgM } \\
2 \text { h after } \\
\text { delivery) }\end{array}$ & $\begin{array}{l}\text { Laboratory analysis (elevated } \\
\text { cytokines and white cell blood } \\
\text { counts) suggestive of neonatal } \\
\text { inflammation and liver injury (1) }\end{array}$ \\
\hline Alonso et al..$^{34}$ & Spain & 1 & $\begin{array}{c}\text { Emergency caesarean section } \\
\text { (severe preeclampsia) }(1)\end{array}$ & No & $\begin{array}{c}\text { - Severe preeclampsia (1) } \\
\text { - LBW (1) } \\
\text { - Neonatal respiratory distress (1) }\end{array}$ \\
\hline Kalafat et al. ${ }^{35}$ & Turkey & 1 & Caesarean section (1) & No & Not reported \\
\hline Lee et al. ${ }^{36}$ & Korea & 1 & $\begin{array}{c}\text { Emergency caesarean section } \\
\text { (1) }\end{array}$ & No & Not reported \\
\hline Gidlöf et al. ${ }^{37}$ & Sweden & 1 (twins) & $\begin{array}{l}\text { Emergency caesarean } \\
\text { section (severe preeclampsia, } \\
\text { gestational diabetes) (1) }\end{array}$ & No & $\begin{array}{c}\text { - Breathing problems (1) } \\
\text { - Vomiting (1) } \\
\text { - LBW (1) }\end{array}$ \\
\hline Zambrano et al. ${ }^{38}$ & Honduras & 1 & Vaginal delivery (1) & No & $\begin{array}{l}\text { - Preterm delivery (1) } \\
\text { - LBW (1) }\end{array}$ \\
\hline Total women & & 124 & & & \\
\hline
\end{tabular}

Abbreviations: LBW, low birth weight; PROM, premature rupture of membranes; ARDS, acute respiratory distress syndrome; SGA, small for gestational age; MODS, multiple organ dysfunction syndrome; ARDS, acute respiratory distress syndrome; PCIS, Pediatric Critical Illness Score; CK-MB, creatine kinase myocardial band; SARS-CoV-2, severe acute respiratory syndrome coronavirus 2; IgG, immunoglobulin G; IgM, immunoglobulin M.

a Not directly related with COVID-19.

Table 2. Summary of case-control studies of coronavirus disease 2019 (COVID-2019) in pregnant women.

\begin{tabular}{|c|c|c|c|c|c|c|c|}
\hline \multirow[b]{2}{*}{ Reference } & \multirow[b]{2}{*}{ Country } & \multicolumn{2}{|c|}{ Infected pregnant women } & \multicolumn{2}{|c|}{ Control pregnant women } & \multirow{2}{*}{$\begin{array}{c}\text { Vertical } \\
\text { transmission }\end{array}$} & \multirow{2}{*}{$\begin{array}{c}\text { Adverse pregnancy/ } \\
\text { neonatal outcomes } \\
\text { in infected women } \\
\text { (n) }\end{array}$} \\
\hline & & $\mathbf{n}$ & $\begin{array}{l}\text { Mode of } \\
\text { delivery }\end{array}$ & $\mathbf{n}$ & $\begin{array}{l}\text { Mode of } \\
\text { delivery }\end{array}$ & & \\
\hline Zhang et al. ${ }^{39}$ & China & 16 & $\begin{array}{l}\text { Caesarean } \\
\text { section }\end{array}$ & 45 & $\begin{array}{l}\text { Caesarean } \\
\text { section }\end{array}$ & No & Not reported \\
\hline Li et al. ${ }^{40}$ & China & $\begin{array}{c}34(18 \\
\text { confirmed, } \\
16 \\
\text { suspected) }\end{array}$ & $\begin{array}{l}\text { - Caesarean } \\
\text { section (30 } \\
\text { of which } 22 \\
\text { emergency) } \\
\text { - Vaginal } \\
\text { delivery (4) }\end{array}$ & $\begin{array}{c}242 \text { ( } 121 \text { from } \\
2019 \text { cohort, and } \\
121 \text { from } 2020 \\
\text { cohort) }\end{array}$ & $\begin{array}{c}\text { - Caesarean } \\
\text { section }(n=101) \\
\text { - Vaginal delivery } \\
(n=141)\end{array}$ & No & $\begin{array}{c}\text { - Preterm delivery (6) } \\
\text { - LBW (5) } \\
\text { - Fetal distress (3) }\end{array}$ \\
\hline Total women & & 50 & & 287 & & & \\
\hline
\end{tabular}

Abbreviation: LBW, low birth weight.

a Significantly higher in comparison with control pregnant women. 


\section{Disease presentation in infected mothers}

A previous review including 108 infected pregnant women in the third trimester described fever (68\%) and coughing (34\%) as the most frequent symptoms of COVID-19, and elevated C-reactive protein $(70 \%)$ and lymphopenia $(59 \%)$ as the most commonly altered maternal parameters ${ }^{41}$.

Several authors suggested that pregnancy did not aggravate the symptoms or computed tomography (CT) features of COVID-19 pneumonia ${ }^{18,42}$. The most common early finding on chest CT was ground-glass opacity, which progressed to 'crazy paving' pattern and consolidations ${ }^{18}$. The most frequent symptoms at onset of COVID-19 were fever (13/15 patients) and cough (9/15), while the most common abnormal laboratory finding was lymphopenia (12/15). Pneumonia was not aggravated after delivery in these women. The results of a point-of-care lung-ultrasound examination were found to correlate with CT findings in one pregnant women; and therefore, this technique has been proposed as a tool to facilitate the triage of mothers with suspected COVID-1935,43.

Liu H. et al. evaluated clinical and CT imaging on 41 COVID-19 infected pregnant women (16 laboratory-confirmed and 25 clinically-diagnosed), in comparison with 14 infected non-pregnant adults ${ }^{44}$. Both laboratory-confirmed and clinicallydiagnosed COVID-19 pregnant groups more frequently presented leukocytosis, elevated neutrophil ratio, and lymphopenia than non-pregnant adults. Mixed and complete consolidation were more commonly observed in the pregnant groups than in non-pregnant adults. Ground-glass opacity with reticulation was less common in the two pregnant groups than in non-pregnant adults. Moreover, the clinically-diagnosed cases showed more pulmonary involvement than the laboratory-confirmed cases. In view of these results, researchers warned that the atypical clinical findings observed in pregnant women with COVID-19 could complicate the initial identification of the disease ${ }^{44}$.

\section{Placental pathology}

In a case series including three pregnant women infected by SARS-CoV-2, all placental histopathological findings included various degrees of fibrin deposition within and around the villi with increased local syncytial nodules, but without villitis or chorioamnionitis $^{19}$. One placenta also showed chorionic hemangioma, and another presented massive placental infarction. However, Chen S. et al. found no placental complications, including placenta infarction or chorionic amniotic inflammation, in five infected pregnant women from Hubei province, in China ${ }^{20}$. Further histolopathological studies of placenta samples are urgently needed.

\section{Maternal, fetal, and neonatal outcomes}

A vast majority of available publications refers to Chinese egnant women. In a case series including three pregnant women infected by SARS-CoV-2, one of the infants was born preterm with low birth weight $(\mathrm{LBW})^{19}$. Other publication presented the case of a 30-week pregnant woman with COVID-19 that gave birth to a LBW but healthy baby ${ }^{21}$.
Liu et al. presented 13 pregnant women infected with SARS-CoV-2, two with less than 28 weeks of gestation and 11 in the third trimester ${ }^{22}$. Three patients improved after hospitalization, were discharged from the hospital, and had an uncomplicated pregnancy. The other ten patients underwent caesarean section, of which five were emergency sections because of fetal distress $(n=3)$, premature rupture of membranes (PROM) $(n=1)$, and stillbirth $(n=1)$. Six patients $(46 \%)$ had preterm labour from 32 to 36 weeks of gestation. The condition of one of the mothers deteriorated during hospitalization, requiring ICU admission with intubation and mechanical ventilation. This woman presented multiple organ dysfunction syndrome (MODS) that comprised of acute respiratory distress syndrome (ARDS), acute hepatic failure, acute renal failure, and septic shock, and was under extracorporeal membrane oxygenation at the time of the study ${ }^{22}$.

Chen H. et al. reported two cases of fetal distress, four cases of preterm delivery (one mother with preeclampsia, one case of PROM and two with previous history of caesarean sections or stillbirth), and two of LBW (the mother with preeclampsia and the case of PROM) among nine pregnant women infected with COVID-1923. Chen R. et al. included 17 infected pregnant women, three of the neonates were prematurely born ${ }^{24}$. One case of newborn death due to endouterine asphyxia was reported in a critically ill pregnant woman with SARS-CoV-2 (who developed severe acute respiratory distress syndrome, multiple organ dysfunction syndrome, and septic shock $)^{25}$. The mother successfully recovered after treatment with convalescent plasma.

Zhu H. et al. found several adverse pregnancy outcomes among nine infected women (clinical symptoms beginning before delivery in four cases, on the day of delivery in two mothers, and after delivery in other three) ${ }^{26}$ Of ten newborns (eight singletons and two twins), six were born premature and two were small for gestational age (SGA) infants. Six of the newborns had a Pediatric Critical Illness Score (PCIS) lower than 90, and showed clinical symptoms including shortness of breath $(n=6)$, fever $(n=2)$, thrombopenia accompanied by abnormal liver function $(n=2)$, rapid heart rate $(n=1)$, and vomiting $(n=1)$. Four neonates presented gastrointestinal symptoms including bloating, refusing milk, feeding intolerance, and gastric bleeding, and seven showed radiography abnormalities (infections, $\mathrm{n}=4$; neonatal respiratory distress syndrome, $\mathrm{n}=2$; and pneumothorax, $\mathrm{n}=1$ ). One infant presented multiple organ failure, refractory shock, and disseminated intravascular coagulation at day 8 after delivery, received a transfusion, and died on day $9^{26}$.

Fan C. et al. reported two cases of COVID-19 during the third trimester of pregnancy showing good outcomes in general ${ }^{27}$. One infant developed low grade fever and abdominal distension with lymphopenia $(16.9 \%)$ on day 3 , and diffuse haziness in both lung fields without patchy consolidation was observed in a chest radiograph on day 4. The fever and lung infection responded to antibiotics, and was discharged on day 9. The second newborn developed mild neonatal pneumonia and 
lymphopenia (10.5\%), and was treated with antibiotics with good response in two days ${ }^{27}$. Chen S. et al. and Yu N. et al. observed good maternal, fetal, and neonatal outcomes in 12 infected pregnant women ${ }^{20,28}$.

Only a few cases of COVID-19 in pregnancy have been reported outside from China. An infected pregnant women in Spain delivered through an urgent caesarean section due to severe preeclampsia $^{34}$. The newborn presented LBW, required resuscitation and was transferred to the neonatal unit due to immediate respiratory distress. The neonate received respiratory support for $2 \mathrm{~h}$ post birth, showing normal findings on the physical examination at $9 \mathrm{~h}$ post birth. The neonate tested negative for SARS-CoV-2 at day 6 post birth, but positive at day 8, showing respiratory symptoms until day 13 , while the mother required ICU care with mechanical ventilation ${ }^{34}$. Kalafat et al. reported the case of a pregnant women in Turkey with lung ultrasound findings consistent with COVID-19, but an initial negative real time PCR (RT-PCR) result that subsequently became positive; the woman delivered a healthy newborn ${ }^{35}$. One Korean mother with COVID-19 delivered a healthy infant through emergency caesarean section due to obstructed labour ${ }^{36}$. In Sweden, one SARS-CoV-2-positive woman with severe preeclampsia and gestational diabetes delivered twins, one was LBW and the other showed respiratory problems and vomiting after birth ${ }^{37}$. In Honduras, a woman with gestational hypertension and hypothyroidism prematurely delivered a LBW infant $^{38}$. Although general media have reported the birth of healthy non-infected infants from SARS-CoV-2 infected mothers in Italy, there is no published scientific literature on the topic yet.

Until now, two case-control studies have been conducted in China (Table 2). Zhang L. et al. compared the pregnancy outcomes of 16 women with COVID-19 (one severe case) and 45 non-infected women, all delivering by caesarean section ${ }^{39}$. Researchers did not observe significant differences in the intraoperative blood loss, meconium-stained amniotic fluid, fetal distress, preterm birth, neonatal asphyxia, or birth weight between infected and non-infected mothers. A second casecontrol study by Li N. et al. compared 16 pregnant women with confirmed COVID-19 pneumonia and 18 suspected cases, all with mild symptoms who were admitted to labour in the third trimester, with two cohorts of 121 age-matched control pregnant women each (one from 2019 and one from 2020) ${ }^{40}$. Around $70 \%$ of the two cases groups presented other maternal complications (mostly gestational diabetes mellitus, gestational hypertension, and hypothyroidism), a percentage significantly higher than in the control groups (33\%). Three confirmed cases (18.8\%, two caused by PROM and one by placental bleeding) and three suspected cases $(16.7 \%$, one due to gestational hypertension/preeclampsia and one due to placenta previa) delivered prematurely, compared with a $5.8 \%$ of the controls. LBW also occurred more often in infants of the two cases groups (17.6\% for confirmed and $10.5 \%$ for suspected cases) than in those of controls (2.5\%). Two newborns from COVID-19 confirmed mothers and one from a suspected case had intrauterine fetal distress, but this percentage was not significantly different from the control groups ${ }^{40}$.

\section{Delivery}

In the great majority of COVID-19 cases reported, mothers delivered by caesarean section (Table 1 and Table 2). Of them, several emergency caesarean sections were performed because the condition of the mother deteriorated, or due to fetal risk (including fetal distress or PROM). Only 11 out of 174 mothers had a vaginal delivery $(6.32 \%)$.

Chen R. et al. evaluated 17 infected patients undergoing caesarean delivery, and found that a significant majority of women with COVID-19 receiving continuous epidural anesthesia presented significant intraoperative hypotension ${ }^{24}$. The team reported an increased use of carbetocin or carboprost tromethamine for the treatment of uterine contraction fatigue in caesarean sections in pregnant women with COVID-19, compared with a non-COVID-19 group ${ }^{39}$.

\section{Mother-to-child transmission}

None of the studies reported vertical transmission of SARSCoV-2 when fetal samples, amniotic fluid, cord blood, or breast milk where tested by RT-PCR ${ }^{18-23,26,27,29,30,34,35,36,39}$. A neonate born to a pregnant woman with SARS-CoV-2 pneumonia tested positive for the infection in pharyngeal swabs $36 \mathrm{~h}$ after birth, but maternal breast milk was negative ${ }^{31}$. $\mathrm{Yu} \mathrm{N}$. et al. found that one out of three neonates tested in throat swabs was positive for SARS-CoV-2 infection $36 \mathrm{~h}$ after birth $^{28}$. Zeng L. et al. reported three neonates born from SARS-CoV-2-positive mothers (out of 33 neonates from infected women investigated) that tested positive for viral infection in nasopharyngeal and anal swabs on days 2 and 4 after birth ${ }^{32}$. In this study, the babies were all born by caesarean section under strict infection control conditions and were immediately separated from their mothers. The outcomes were favourable, and infected neonates only showed a mild presentation with shortness of breath and non-specific radiographic findings (with the exception of a seriously ill probably due to prematurity, asphyxia, and sepsis, rather than SARS-CoV-2 infection). One case report presented a $2 \mathrm{~h}$ newborn with elevated immunoglobulin $\mathrm{G}$ ( $\mathrm{IgG})$ and immunoglobulin $\mathrm{M}(\operatorname{IgM})$ antibodies to SARS-CoV-2 born to a mother with COVID-19 ${ }^{33}$. Infant's nasopharyngeal swabs, maternal vaginal secretions at delivery, and breast milk were negative for SARS-CoV-2. Laboratory analysis suggested inflammation and liver injury in the newborn. Since IgM antibodies cannot cross the placenta, further research is needed to confirm this observation, and whether intrauterine or perinatal SARS-CoV-2 infection occurred in these studies.

Zheng Q.L. et al. found that ACE2 expression is minimal in almost all cell types of the early maternal-fetal interface in humans, with the exception of decidual perivascular cells cluster ${ }^{45}$. This observation may suggest that the susceptibility of cells in the maternal-fetal interface to COVID-19 could be low, limiting the probabilities of transplacental vertical transmission of SARS-CoV-2. On the contrary, Levy et al. found that ACE2 expression and activity are increased during pregnancy in rat models, in particular in the placenta but also in the uterus ${ }^{46}$. Reduced expression of ACE2 has been linked to fetal growth 
restriction, both in humans and rats ${ }^{47,48}$. Further experimental studies are needed to discern the link between ACE2 expression, SARS-CoV-2 susceptibility, and pregnancy outcomes.

\section{Pooled data}

A WHO joint mission recently investigated 147 pregnant women (64 confirmed, 82 suspected and 1 asymptomatic; 8\% with severe disease and 1\% critical) and suggested that pregnancy does not appear as a risk factor for severe COVID-19 disease, as opposed to pandemic influenza A (H1N1)pdm09 ${ }^{49}$. The report concluded that having COVID-19 during pregnancy may have an impact on fetal outcomes.

A previous review about COVID-19 in pregnancy included published studies until the 25th February 2020, and was used to inform the UK Royal College of Obstetricians and Gynaecologists guidance ${ }^{50}$. This review found that preterm delivery affected $47 \%$ of women $(n=32)$ hospitalized with COVID-19. There were no maternal deaths and serious morbidity requiring intensive care unit (ICU) admission occurred in two out of $32(6.25 \%)$ reviewed cases. A second review including 37 mothers reported 6 cases $(16.2 \%)$ of preterm labour, $6(16.2 \%)$ of PROM, $2(5.40 \%)$ with abnormal amniotic fluid, and $2(5.40 \%)$ with abnormal umbilical cord ${ }^{51}$. A review published on 17th March 2020 reported preterm birth in 39\% of cases, intrauterine growth restriction in $10 \%$, and miscarriage in $2 \%$. A review published on 7th April including 108 women noted three cases of maternal ICU admissions, one neonatal death and one intrauterine death, with $91 \%$ of deliveries by caesarean section ${ }^{41}$.

Since the publication of these reviews, several new cases of infected pregnant women have been reported, a great majority of them including Chinese pregnant women and only a few case reports from other settings. Among the 174 cases included in this review, a majority of the mothers did not show severe complications related with COVID-19 infection, in particular from mid-trimester onwards. The predominant presentation of COVID-19 in pregnancy included fever, cough, dyspnea, and lymphopenia, as previously reported ${ }^{52}$. Data on first-trimester COVID-19 infection and subsequent follow-up are lacking. It is unknown whether pregnant women have an increased susceptibility to SARS-CoV-2 infection, and there is no evidence from SARS or MERS about an increased susceptibility during pregnancy. However, several publications reported adverse pregnancy and neonatal outcomes in pregnant women infected by SARS-CoV-2.

Regarding pregnancy outcomes in the 174 women with COVID-19, there were 29 cases of preterm delivery $(16.7 \%)$, 17 cases of fetal distress $(9.77 \%)$, three cases of PROM $(1.72 \%)$, two cases of SGA $(1.15 \%)$, one stillbirth $(0.57 \%)$, and one fetal death $(0.57 \%)$. Regarding neonatal outcomes $(n=176$ since there were two births of twins), there were 14 newborns with respiratory problems (including shortness of breath and pneumonia, $7.95 \%), 12$ with LBW $(6.81 \%)$, five with fever $(2.84 \%)$, three with gastrointestinal problems $(1.70 \%)$, three with lymphopenia $(1.70 \%)$, three with thrombopenia $(1.70 \%)$, two with tachycardia (1.14\%), and one infant death $(0.57 \%)$ (Table 1 and Table 2). These percentages should be interpreted cautiously, since at this point we cannot exclude that some women have been included in more than one publication. Similarly, we cannot exclude that other maternal conditions may potentially confound the results, or even interact with COVID-19. A few cases of preeclampsia and gestational diabetes, among others, were reported in the pregnant women included in this calculations. Interestingly, a case-control study in China found that other maternal complications, such as gestational diabetes mellitus, gestational hypertension, and hypothyroidism, were more frequent in women with COVID-19 than in control women. Further research is needed to understand whether pregnant women with other comorbidities are more susceptible to SARS-CoV-2 infection.

Until more evidences are collected in larger studies and in different settings, the current observations suggest that COVID-19 may be potentially associated with adverse pregnancy outcomes, including preterm delivery and fetal distress, and adverse neonatal outcomes including respiratory problems and LBW. Therefore, special attention should be paid to infected women along the gestational period and at the time or delivery, or to those pregnant women that may be eventually exposed to SARS-CoV-2 virus.

\section{Can we learn something from other viral respiratory infections in pregnancy?}

Acute lower respiratory tract illness caused by viral infection, mostly human rhinovirus, respiratory syncytial virus, and influenza virus, is common during pregnancy and associated with significant morbidity ${ }^{17}$. In particular, infection is a relevant cause of morbidity and mortality among future mothers ${ }^{53}$. Pneumonia during pregnancy is related with a higher risk of maternal death and pregnancy-related complications; including preterm delivery, caesarean section, preeclampsia/eclampsia, and LBW and SGA newborns ${ }^{53}$. The consequences of influenza on pregnant women and fetuses have been widely studied, but less is known about the impact of other viral acute respiratory illnesses in this population. In this section we summarize previous studies about infections with SARS-CoV, MERS-CoV, other coronaviruses, and influenza virus during pregnancy (Table 3).

\section{SARS-COV}

SARS-CoV is a zoonotic virus from the betacoronaviridae genus first identified in $2003^{54}$. SARS-CoV and SARS-CoV-2 are closely related (around $79 \%$ of genome sequence identity) and originated in bats, which have been proposed as a reservoir host for the two viruses ${ }^{3}$. Between 2002 and 2003, SARS-CoV caused an epidemics that affected more than 8000 people and resulted in around 1000 deaths in 29 countries, mostly in China and Hong Kong, as reported by the WHO. The illness caused by SARS-CoV frequently initiated with fever and mild respiratory symptoms, but progressed to pneumonia within a few days, and eventually led to respiratory distress requiring intensive care. The WHO estimated an overall case fatality rate of $14-15 \%$. 


\section{Table 3. Summary of the impact of several viral respiratory infections during pregnancy.}

\begin{tabular}{|c|c|c|c|c|}
\hline Virus & $\begin{array}{c}\text { Increased maternal } \\
\text { disease severity }\end{array}$ & $\begin{array}{c}\text { Adverse maternal } \\
\text { outcomes }\end{array}$ & $\begin{array}{c}\text { Adverse fetal } \\
\text { outcomes }\end{array}$ & $\begin{array}{c}\text { Vertical } \\
\text { transmission }\end{array}$ \\
\hline SARS-CoV & ++ & ++ & ++ & - \\
\hline MERS-CoV & + & ++ & ++ & - \\
\hline Other CoV & - & - & - & $+?$ \\
\hline Influenzab & ++ & ++ & + & + \\
\hline SARS-CoV2 & $-?$ & $+?$ & $+?$ & $-?$ \\
\hline
\end{tabular}

Symbols indicate: frequently reported $(++)$, reported in some cases $(+)$, not reported $(-)$, presumable in view of the currently limited evidences (?).

Abbreviations: SARS, severe acute respiratory syndrome; CoV, coronavirus; MERS, Middle East respiratory syndrome.

a Limited evidence available.

${ }^{b}$ A majority of studies analysed pandemic influenza, not seasonal influenza. Maternal severe infections, but not mild, seem to have a stronger impact on pregnancy.

Several case reports and small clinical studies documented relatively few cases of SARS occurring during pregnancy, with estimations forecasting around 100 pregnant women infected during the 2003 epidemics ${ }^{55}$. Although vertical transmission was not observed, SARS-CoV infection was associated with severe maternal illness or even maternal death, spontaneous abortion, severe intrauterine growth retardation, preterm delivery, and life-threatening gastrointestinal complications in the newborn $^{18,56,57}$. A case-control study investigating the effects of SARS on pregnancy found a higher mortality rate (30\% maternal mortality vs. no deaths in non-pregnant), more frequent renal failure and disseminated intravascular coagulopathy, more frequent admission to the ICU, and higher intubation rate in pregnant SARS patients compared with a non-pregnant infected cohort $^{58}$.

$\mathrm{Ng}$ W.F. et al. evaluated the placental pathology of SARS-CoV infection in seven women ${ }^{59}$. The placentas from women with SARS infection detected along the first trimester of pregnancy were normal. On the contrary, the placentas from women convalescent from SARS during the third trimester showed increased intervillous or subchorionic fibrin, probably associated with disturbances in placental blood flow due to the hypoxic respiratory disease. The delivery outcomes of women convalescent during the third trimester included intrauterine growth retardation and SGA newborns. The placentas from women with acute SARS infection were also highly abnormal, showing extensive fetal thrombotic vasculopathy, probably caused by placental hypoxia, with sharply demarcated zones of avascular fibrotic villi at delivery ${ }^{59}$. Clinical guidelines have been published for the management of obstetric patients and neonates born to mothers with suspected or probable SARS ${ }^{60}$. The WHO declared SARS epidemics as contained in July 2003, and the latest outbreak in China was contained in May 2004.

MERS-CoV. MERS-CoV is a betacoronavirus causing respiratory disease, which was first identified in Saudi Arabia in $2012^{61}$. From 2012 until the end of January 2020, the total number of laboratory-confirmed MERS-CoV cases reported globally to the WHO were 2519, with 866 associated deaths (around 35\% estimated mortality). Since 2012, 27 countries have reported cases of MERS, although $80 \%$ of them occurred in Saudi Arabia, according to the WHO. Humans can be infected with MERS-CoV from direct or indirect contact with dromedaries, although the virus can also be transmitted between humans in close contact. The clinical presentation of MERS-CoV infection widely ranges from absence of symptoms or mild respiratory symptoms to severe acute respiratory disease, and even death. Pneumonia is frequent, and gastrointestinal symptoms have also been described. Severe illness can lead to respiratory failure that requires ICU support with mechanical ventilation. The severity of the disease increases with age, in immunosuppressed people, and in those with chronic conditions such as renal or respiratory diseases, cancer, and diabetes.

Information about the pathophysiology of MERS-CoV infection during pregnancy is scarce, but pregnant women are thought to develop severe disease and adverse maternal and fetal outcomes. A retrospective study conducted in Saudi Arabia between 2012 and 2016 included five pregnant women infected with MERS-CoV during the second or third trimester of pregnancy, all requiring ICU care and showing adverse pregnancy outcomes ${ }^{62}$. Among them, two women died, and two pregnancies resulted in perinatal death. A case report presented a stillbirth, while a second one reported the delivery of a healthy infant, with both women requiring ICU care ${ }^{63,64}$. One mother died in Abu-Dhabi after delivering a healthy baby by caesarean section ${ }^{65}$. One asymptomatic woman delivered a healthy infant ${ }^{66}$. In South Korea, a MERS-CoV-infected mother had abrupt vaginal bleeding with membranes rupture, and delivered a healthy baby by caesarean section ${ }^{67}$. About $10 \%$ placental abruption was found in this patient. Considering all these cases, the estimated maternal case fatality rate in pregnant women is not significantly different than the overall case 
fatality rate by MERS-CoV infection, while the disease has resulted in $27 \%$ of fetal/infant deaths ${ }^{66}$.

In view of the available information, maternal outcomes in COVID-19 appear less concerning compared to those of SARS and MERS. Pooled data found a case fatality rate of $0 \%$ for COVID-19, 18\% for SARS, and 25\% for MERS, being severe sepsis and respiratory failure the most frequent causes of maternal death in the last two infections ${ }^{52}$.

Other coronaviruses. At least four other types of coronaviruses (alphacoronaviruses HCoV-229E and HCoV-NL63 and betacoronaviruses $\mathrm{HCoV}-\mathrm{OC} 43$ and $\mathrm{HCoV}-\mathrm{HKU} 1)$ are known to infect humans causing mild, self-limiting respiratory infections. These viruses cause around $15-30 \%$ of respiratory tract infections each year, with more severe presentation in neonates, the elderly, or individuals with underlying conditions ${ }^{68}$. A prospective pilot study evaluated the potential maternal-fetal transmission of these coronaviruses ${ }^{69}$. The results suggested the possibility of vertical transmission of human coronaviruses, in particular $\mathrm{HCoV}-229 \mathrm{E}$, which was detected in three out of four newborn gastric samples whose mothers tested positive in vaginal samples collected at delivery. Two of these mothers were also positive in respiratory samples, and none of the infants showed clinical symptoms. Further studies are needed to understand the potential intrauterine transmission, as well as the effect over pregnancy outcomes, of these coronavirus infections.

A detailed discussion of the epidemiological and clinical impact of SARS, MERS, and other coronavirus infections on pregnant women and newborns can be found in a recently published perspective $\operatorname{article}^{70}$.

Influenza virus. Influenza viruses are enveloped viruses with segmented negative-sense single-strand RNA genome, members of the family Orthomyxoviridae. This family comprises several genera, including influenza A viruses infecting humans and several animals with pandemic potential; influenza $B$ viruses that circulate among humans and cause seasonal epidemics; influenza $C$ viruses that can infect humans with mild presentation, as well as pigs; and influenza D viruses that primarily affect cattle (see WHO influenza page). Influenza A virus infections can cause human diseases ranging from mild upper respiratory tract infection with fever and cough to severe pneumonia, sepsis with shock, acute respiratory distress syndrome, and even death. Seasonal influenza caused by influenza A or B virus subtypes is characterized by a fast onset of fever, cough, headache, severe malaise, muscle and joint pain, sore throat, and rhinorrhea, which can cause severe illness or death especially in high-risk populations (children under five, the elderly, or individuals with chronic diseases or immunosuppressive conditions).

Influenza infection in pregnant women has been associated with increased severity, adverse maternal and fetal outcomes, and a higher risk of death. Moreover, women also have an increased risk of death from pandemic influenza during the four weeks post-partum ${ }^{71}$. Substantial evidences were obtained from the influenza pandemic of 1918 to 1919,1957 to 1958 , and 2009 to 2010, and many studies have been published on this topic. For example, the mortality rate of the 1918 influenza pandemic in Iceland reached $37 \%$ among pregnant women, while it was around $2.6 \%$ in the general population ${ }^{72}$. In 2009 , pregnant women were $1 \%$ of patients in the US infected with influenza A H1N1 virus, accounting for $5 \%$ of deaths ${ }^{73}$. The increased severity of influenza during pregnancy and postpartum is thought to be related to the normal physiologic changes occurring during pregnancy, including the hormone-regulated shift in immune responses, decreased lung capacity, and augmented heart rate and oxygen consumption ${ }^{74,75}$. The WHO recommends the inactivated influenza vaccine for all pregnant women independently of the trimester of pregnancy ${ }^{76}$.

A few systematic reviews and meta-analyses have been conducted to summarize the results of the abundant literature about influenza infection in pregnancy. A meta-analysis published in 2017 found that influenza during pregnancy resulted in a 2.5-fold higher risk of hospital admission compared with non-pregnant adults, but the risk of mortality was similar in both groups ${ }^{10}$. Similar results were found in a meta-analysis published in 2019 including 36,498 women, although the risk of hospital admission was almost seven-fold higher in pregnant women than in non-pregnant individuals, and they observed an association between pregnancy and a reduced risk of ICU $\operatorname{admission}^{77}$.

Several clinical studies reported complications related to pandemic influenza infection in fetuses and neonates, particularly those born from mothers with severe infection, including miscarriage, preterm birth, stillbirth, neonatal death, and $\mathrm{LBW}^{78-80}$. A systematic review of comparative studies from 2017 confirmed the increased risk of preterm birth following severe pandemic H1N1 influenza illness, but not in mild-tomoderate pandemic $\mathrm{H} 1 \mathrm{~N} 1$ or seasonal influenza infections ${ }^{81}$. This study found that evidences for the increased risk of SGA birth and fetal death were limited. Littauer E.Q. et al. suggested that H1N1 virus infection during pregnancy results in dysregulated inflammatory responses leading to preterm labour, impairment of fetal growth, and increased fetal mortality and maternal morbidity in animal models ${ }^{82}$.

A meta-analysis including 22 studies showed that first trimester maternal influenza exposure is associated with an augmented risk of several non-chromosomal congenital anomalies, including neural tube defects, hydrocephaly, congenital heart defects, among others, although exposure to influenza-related medication was not assessed ${ }^{83}$. Previous work suggested a link between influenza infection during pregnancy and psychotic disorders in the offspring, particularly in mothers with psychiatric disorders $^{84,85}$, but the evidences are currently insufficient to draw a conclusion ${ }^{86}$. Transplacental transmission of influenza virus has been rarely reported in the literature, but evidence exists that suggests that the virus can cross the placenta ${ }^{87}$.

A WHO technical consultation identified several quality issues (potential confound biases, methodological limitations, 
inconsistent definitions, etc.) and evidence gaps in the current knowledge about the risks of severe influenza outcomes among pregnant women, the risks to the fetus, and the effects of maternal immunization ${ }^{88}$. In particular, evidence is lacking for seasonal influenza, for the impact of other contextual factors such as malnutrition or co-infections, as well as evidence from low-resource settings and long-term safety data regarding vaccination in pregnant women ${ }^{88}$. As this report suggests, even in the case of influenza infection in pregnant women where numerous studies have been conducted, many questions remain unanswered.

\section{Care and management of pregnant women and newborns during COVID-19 pandemic}

Interim recommendations

In view of the scarce knowledge about COVID-19 in pregnancy and the similar pathogenic potential as SARS-CoV and MERS-CoV, several authors have highlighted in letters and perspectives the need for a systematic screening and careful follow-up of any suspected SARS-CoV-2 infection during pregnancy ${ }^{89,90}$. Several organizations have issued interim guidance specific to pregnant women, and several individual expert opinions have been published giving recommendations based on their institutional experiences.

The WHO published on 13th March 2020 an interim guidance for the clinical management of severe acute respiratory infection when COVID-19 is suspected, which includes recommendations for pregnant women ${ }^{91}$. In this document, the WHO specifically states that pregnant women with suspected or confirmed COVID-19 should be treated with supportive and management therapies, considering the immunologic and physiologic adaptations during and after the gestational period ${ }^{91}$. It also emphasizes the need to prioritize COVID-19 testing of symptomatic pregnant women to enable access to specialized care. WHO recommends caesarean section to be only undertaken when medically justified, and highlights that the mode of delivery should be decided based on obstetric indications and the woman's preferences. Infants born to mothers with suspected or confirmed COVID-19 infection should be fed according to standard infant feeding guidelines, and thus breastfeeding is encouraged following strict hygienic practices. Moreover, this interim guidance mentions that mothers and infants should remain together and practice skin-to-skin contact, in particular immediately after birth during establishment of breastfeeding, also when they or their infants have suspected or confirmed SARS-CoV-2 infection. If the mother is severely or critically ill, separation could be needed, with attempts to express breast milk to maintain milk production ${ }^{91}$. Similarly, the Centers for Disease Control and Prevention (CDC) from the US have prepared some interim considerations for infection prevention and control of COVID-19 in inpatient obstetric healthcare settings'. The International Society of Ultrasound in Obstetrics \& Gynecology (ISUOG), the European Centre for Disease Prevention and Control (ECDC), and other national health authorities have also published interim recommendations for management of infection during pregnancy and puerperium ${ }^{92-94}$. In Italy, one of the countries most affected by the pandemic, the health authorities state that caesarean section does not seem appropriate unless there are specific clinical indications. Moreover, they recommend health professionals and mothers to carefully consider together any temporary separation of the infant from the mother during hospitalization, evaluating the risks and benefits of this choice, and advises breastfeeding under strict measures of infection control $^{95}$. The International Federation of Gynecology and Obstetrics (FIGO) published on 4th April the most up-to-date interim guidance on COVID-19 during pregnancy and puerperium $^{96}$.

In the studies including Chinese pregnant women with COVID-19, the majority of patients delivered through caesarean section, the neonates were isolated immediately after birth for at least 14 days, and breastfeeding was not recommended. The National Health Commission of China, after expert consensus, issued recommendations on 8th February 2020 emphasizing that neonates of pregnant women with suspected or confirmed COVID-19 infection should be isolated in a designated unit for at least 14 days after birth, and not be directly breastfed ${ }^{97,98}$. These recommendations generated some controversy ${ }^{99,100}$ and have been updated in some Chinese settings to promote breastfeeding and neonatal isolation only of newborns with confirmed SARS-CoV-2 infection ${ }^{101}$.

Special attention should be paid to pregnant healthcare workers, and some countries have already recommended to those after 28 weeks of pregnancy to avoid direct contact with SARS-CoV-2-infected patients ${ }^{102}$.

The existence of disseminated intravascular coagulation (DIC) is common in deaths of COVID-19 patients, and abnormal coagulation parameters have been associated with poor $\operatorname{prognosis}^{103}$. During pregnancy, women are at increased risk for hemorrhagic events and obstetrical syndromes that may develop into DIC, usually associated with high mortality and morbidity rates $^{104}$. Additionally, women with SARS-CoV infection showed higher risk of $\mathrm{DIC}^{58}$. Although alterations in coagulation processes have not been reported in pregnant women infected with SARS-CoV-2, obstetric teams should evaluate this risk and consequently adapt the anticoagulation therapeutic plan during and after the hospitalisation of pregnant women.

Diagnosis of SARS-CoV-2 in pregnant women. A CT scan of the chest is a primary tool to confirm or exclude SARS-CoV-2 pneumonia, complementing RT-PCR diagnosis ${ }^{105}$. The majority of reported pregnant women with COVID-19 infection showed radiological signs of viral pneumonia ${ }^{23}$. Chest $\mathrm{CT}$ scan has been recommended in suspected cases of COVID-19 in pregnant women, since the risk of radiation exposure to the fetus is small $^{92}$. However, shared decision-making should be encouraged. In any case, informed consent is needed, and a radiation shield should be applied over the uterus ${ }^{92}$.

Recommendations for the obstetrics units. In the present emergency situation, the obstetrics units need to be reorganized without delay, and several recommendations have been made in 
this sense $^{106}$. These recommendations include the preparation of a closed circuit for all COVID-19 positive patients separated from non-infected patients, whenever possible. The ISUOG has prepared a position statement to guide the safe performance of obstetric and gynecological scans and equipment cleaning in the context of COVID-19 pandemic ${ }^{107}$. The document refers to ultrasound in particular, which places the patient and the caregiver at high risk because of the impossibility of maintaining the safety distance. Ultrasound is an essential tool of obstetric and gynecological care, and therefore what constitutes an elective or an emergency examination has to be decided locally ${ }^{107}$. The expert-opinion-based guidance from the ISUOG focuses on two aspects: first, the preparation and cleaning of the room and the ultrasound equipment; and second, the protection of the patient and ultrasound operators (physicians, sonographers and other health professionals).

Drugs and vaccines against COVID-19: what happens with pregnant women? Currently, there are no specific treatments for COVID-19. More than 80 clinical trials are ongoing, some of them on repurposed drugs and, therefore, in more advanced clinical stages. WHO has recently launched the SOLIDARITY trial (ISRCTN83971151) of treatments for COVID-19 infection in hospitalized patients. The study treatments under evaluation are the experimental antiviral remdesivir, the antimalarials chloroquine or hydroxychloroquine, the combination of human immunodeficiency virus (HIV) drugs lopinavir/ritonavir, and interferon-beta. These drugs were selected based on the likelihood of being effective, previous safety data, and expected wide availability. Simultaneously, the DISCOVERY trial (NCT04315948) of treatments for COVID-19 in hospitalized adults will be conducted in several European countries to evaluate the safety and efficacy of the same drugs, with the exception of chloroquine. Similarly to all decisions regarding treatment during pregnancy, careful assessment of the risk-benefit ratio both for the mother and the fetus is indispensable. It seems reasonable not to exclude seriously ill pregnant women from trials of these experimental drugs for COVID-1950.

Remdesivir and lopinavir/ritonavir appear to be safe in pregnancy $^{52}$. Chloroquine phosphate has shown apparent efficacy and an acceptable safety profile against COVID-19-associated pneumonia in multicentre clinical trials conducted in China ${ }^{108}$. However, special attention should be put to the use of the antimalarial chloroquine in pregnant women. Previous pharmacokinetic studies of chloroquine and its active metabolite observed differences in the elimination half-lives and in the volumes of distribution and clearance when compared with age-matched non-pregnant women ${ }^{109}$. This translates in a reduced plasma concentration of chloroquine in pregnant women that could compromise the antiviral effect, while higher doses may increase the risk of adverse hemodynamic effects. Hydroxychloroquine (with a maximum tolerable dose of $1200 \mathrm{mg}$ ), also used in women with rheumatic diseases, could be a therapeutic alternative to chloroquine (with a maximum tolerable dose of $500 \mathrm{mg}$ ) in pregnant women because of its safety profile, with the potential to be administered at a higher dosage $\mathrm{e}^{110}$.
If the deleterious effect of COVID-19 in pregnancy is confirmed, maternal immunization must constitute a priority and pregnant women should be considered in any prevention effort. As some researchers have highlighted, pregnant women should be included in the design, evaluation, and implementation of vaccine candidates for SARS-CoV-2 ${ }^{111}$.

Physical and mental health of pregnant women during COVID-19 pandemic. The mental challenges that the pandemic may pose in pregnant women should be carefully considered, and health authorities should implement programs to provide counselling and psychological support to future mothers. Stress and anxiety during pregnancy seem to be related with side effects such as depression, preeclampsia, preterm labour, LBW, and others ${ }^{112,113}$. $\mathrm{Ng} \mathrm{J}$. et al. revealed the pivotal role of midwives in providing care, health education, and counselling to pregnant women during and after the crisis posed by the 2003 SARS epidemics in Hong Kong ${ }^{114}$.

In addition to an adequate management of stress and anxiety, a lifestyle including appropriate nutrition, moderate physical activity, and plenty of sleep could help pregnant women to stay healthy during COVID-19 pandemic. Emphasis should be put on the practice of regular exercise at home or away from other people if no contraindications exist. Moderate physical exercise during pregnancy has previously demonstrated benefits both for the mother and the fetus, including the reduction of back pain, the promotion of healthy weight gain, and the reduction of the risk of gestational diabetes, preeclampsia, and caesarean delivery (for example, recommendations from The American College of Obstetricians and Gynecologists) ${ }^{115}$.

Pregnant women in low-resource settings. Maternal mortality remains unacceptably high (around 295000 deaths in 2017), with $94 \%$ of deaths occurring in low- and middle-income countries $^{116}$. Infections remain one of the main causes of maternal death and adverse pregnancy outcomes in these settings. With SARS-CoV-2 present in every country of the world and the number of cases escalating, it is unclear how fragile health systems will be able to confront the pandemic. In this context, pregnant women and neonates in low-resource areas, as well as refugees and those in conflict zones, emerge as one of the most vulnerable populations. Moreover, we have no clues on the potential impact of comorbidities, such as tuberculosis or HIV infections, obstetric complications or malnutrition, on pregnant women with COVID-19. Experience from previous disease outbreaks revealed the disruptive effect on health service delivery and the consequences for diseases such as malaria, which mostly affects children and pregnant women. The WHO has already urged countries to continue to guarantee the delivery of malaria services in the context of the pandemic, including chemopreventive treatment in pregnant women and infants. Similarly, other current efforts regarding women's, infant's, and children's health and healthcare should be guaranteed. Effective coordination, collaboration, and communication are more necessary than ever to protect pregnant women and their infants globally. 


\section{Conclusions}

Although pregnant women do not seem to present an increased susceptibility to COVID-19 or more severe complications than non-pregnant adults, the available studies suggest that they may be at risk of adverse pregnancy outcomes, mostly preterm delivery, fetal distress, respiratory symptoms and LBW in the newborns. Analysis of the impact of COVID-19 on pregnancy regarding the ongoing trimester is needed in detail. Further research is urgently needed to understand the real effect of COVID-19 on pregnant women and neonates, and to guide the most appropriate recommendations for obstetricians. Only an integrated multiangle assessment of the current knowledge about viral characteristics, COVID-19 epidemiology, disease immunopathology, and potential preventive and therapeutic strategies, together with clinical observations, will help to understand the exact impact of COVID-19 infection during pregnancy.

\section{Data availability}

Underlying data

No data are associated with this article.

\section{Acknowledgements}

We would like to thank Prof. Rene Frydman and Prof. Jean-Marc Ayoubi for their help, advice, visions, and excellent recommendations.
1. Zhu N, Zhang D, Wang W, et al.: A Novel Coronavirus from Patients with Pneumonia in China, 2019. N Engl J Med. 2020; 382(8): 727-733. PubMed Abstract | Publisher Full Text | Free Full Text

2. World Health Organization: Coronavirus Disease 2019 (COVID-19) Situation Report-78. 2020.

Reference Source

3. Andersen KG, Rambaut A, Lipkin WI, et al.: The proximal origin of SARS-CoV-2. Nat Med. 2020; 26(4): 450-452.

PubMed Abstract | Publisher Full Text | Free Full Text

4. Zhang T, Wu Q, Zhang Z: Probable Pangolin Origin of SARS-CoV-2 Associated with the COVID-19 Outbreak. Curr Biol. 2020; 30(7): 1346-1351.e2. PubMed Abstract | Publisher Full Text | Free Full Text

5. Zhou $P$, Yang $X L$, Wang $X G$, et al:: A pneumonia outbreak associated with a new coronavirus of probable bat origin. Nature. 2020; 579(7798): 270-273. PubMed Abstract | Publisher Full Text | Free Full Text

6. Letko M, Marzi A, Munster V: Functional assessment of cell entry and receptor usage for SARS-CoV-2 and other lineage B betacoronaviruses. Nat Microbiol. 2020; 5(4): 562-569.

PubMed Abstract | Publisher Full Text | Free Full Text

7. Wu Z, McGoogan JM: Characteristics of and Important Lessons From the Coronavirus Disease 2019 (COVID-19) Outbreak in China: Summary of a Report of 72314 Cases From the Chinese Center for Disease Control and Prevention. JAMA. 2020

PubMed Abstract | Publisher Full Text

8. Istituto Superiore di Sanità: Report about the Characteristics of Death Patients Positive to COVID-19 in Italy (Based on Data Updated on 17th March 2020).

9. He J, Liu ZW, Lu YP, et al.: A Systematic Review and Meta-Analysis of Influenza A Virus Infection During Pregnancy Associated with an Increased Risk for Stillbirth and Low Birth Weight. Kidney Blood Press Res. 2017; 42(2): 232-243. PubMed Abstract | Publisher Full Text

10. Mertz D, Geraci J, Winkup J, et al.: Pregnancy as a risk factor for severe outcomes from influenza virus infection: A systematic review and metaanalysis of observational studies. Vaccine. 2017; 35(4): 521-528. PubMed Abstract | Publisher Full Text | Free Full Text

11. Bergløv A, Hallager S, Weis N: Hepatitis E during pregnancy: Maternal and foetal case-fatality rates and adverse outcomes-A systematic review. $J$ Viral Hepat. 2019; 26(11): 1240-1248.

PubMed Abstract | Publisher Full Text

12. Shi TL, Huang LJ, Xiong YQ, et al.: The risk of herpes simplex virus and human cytomegalovirus infection during pregnancy upon adverse pregnancy outcomes: A meta-analysis. J Clin Virol. 2018; 104: 48-55. PubMed Abstract | Publisher Full Text

13. Niyibizi J, Zanré N, Mayrand MH, et al:: Association Between Maternal Human Papillomavirus Infection and Adverse Pregnancy Outcomes: Systematic Review and Meta-Analysis. J Infect Dis. 2020: pii: jiaa054. PubMed Abstract | Publisher Full Text

14. Thompson JM, Eick SM, Dailey C, et al.: Relationship Between PregnancyAssociated Malaria and Adverse Pregnancy Outcomes: a Systematic Review and Meta-Analysis. J Trop Pediatr. 2019. pii: fmz068. PubMed Abstract | Publisher Full Text

15. Silasi M, Cardenas I, Kwon JY, et al.: Viral Infections During Pregnancy. Am J Reprod Immunol. 2015; 73(3): 199-213. PubMed Abstract | Publisher Full Text | Free Full Text
16. Kourtis AP, Read JS, Jamieson DJ: Pregnancy and Infection. N Engl J Med. 2014; 370(23): 2211-2218 Publisher Full Text

17. Hause AM, Avadhanula V, Maccato ML, et al.: A Cross-sectional Surveillance Study of the Frequency and Etiology of Acute Respiratory Illness Among Pregnant Women. J Infect Dis. 2018; 218(4): 528-535. PubMed Abstract | Publisher Full Text | Free Full Text

18. Wong SF, Chow KM, Leung TN, et al.: Pregnancy and perinatal outcomes of women with severe acute respiratory syndrome. Am J Obstet Gynecol. 2004; 191(1): 292-297.

PubMed Abstract | Publisher Full Text | Free Full Text

19. Chen S, Huang B, Luo DJ, et al.: [Pregnant Women With New Coronavirus Infection: A Clinical Characteristics and Placental Pathological Analysis of Three Cases]. Zhonghua Bing Li Xue Za Zhi. 2020; 49(0): E005. PubMed Abstract | Publisher Full Text

20. Chen S, Liao E, Shao Y: Clinical analysis of pregnant women with 2019 novel coronavirus pneumonia. J Med Virol. 2020. PubMed Abstract | Publisher Full Text

21. Wang X, Zhou Z, Zhang J, et al.: A case of 2019 Novel Coronavirus in a pregnant woman with preterm delivery. Clin Infect Dis. 2020. pii: ciaa200. PubMed Abstract | Publisher Full Text | Free Full Text

22. Liu $\mathrm{Y}$, Chen $\mathrm{H}$, Tang $\mathrm{K}$, et al:: Clinical manifestations and outcome of SARSCoV-2 infection during pregnancy. J Infect. 2020; pii: S0163-4453(20)30109-2. PubMed Abstract | Publisher Full Text | Free Full Text

23. Chen $\mathrm{H}$, Guo J, Wang $\mathrm{C}$, et al:: Clinical characteristics and intrauterine vertical transmission potential of COVID-19 infection in nine pregnant women: a retrospective review of medical records. Lancet. 2020; 395(10226): 809-815. PubMed Abstract | Publisher Full Text | Free Full Text

24. Chen R, Zhang Y, Huang L, et al.: Safety and efficacy of different anesthetic regimens for parturients with COVID-19 undergoing Cesarean delivery: a case series of 17 patients. Can J Anesth. 2020. PubMed Abstract | Publisher Full Text | Free Full Text

25. Zhang B, Liu S, Tan T, et al.: Treatment with convalescent plasma for critically ill patients with SARS-CoV-2 infection. Chest. 2020; pii: S0012-3692(20)30571-7. PubMed Abstract | Publisher Full Text

26. Zhu $\mathrm{H}$, Wang L, Fang $\mathrm{C}$, et al.: Clinical analysis of 10 neonates born to mothers with 2019-nCoV pneumonia. Transl Pediatr. 2020; 9(1): 51-60. PubMed Abstract | Publisher Full Text | Free Full Text

27. Fan C, Lei D, Fang C, et al:: Perinatal Transmission of COVID-19 Associated SARS-CoV-2: Should We Worry? Clin Infect Dis. 2020; pii: ciaa226. PubMed Abstract | Publisher Full Text | Free Full Text

28. Yu N, Li W, Kang Q, et al.: Clinical features and obstetric and neonatal outcomes of pregnant patients with COVID-19 in Wuhan, China: a retrospective, single-centre, descriptive study. Lancet Infect Dis. 2020; 20(5): 559-564.

PubMed Abstract | Publisher Full Text | Free Full Text

29. Li Y, Zhao R, Zheng S, et al:: Lack of Vertical Transmission of Severe Acute Respiratory Syndrome Coronavirus 2, China. Emerg Infect Dis. 2020; 26(6). PubMed Abstract | Publisher Full Text

30. Xia $\mathrm{H}, \mathrm{Zhao} \mathrm{S,} \mathrm{Wu} \mathrm{Z,} \mathrm{et} \mathrm{al.:} \mathrm{Emergency} \mathrm{Caesarean} \mathrm{delivery} \mathrm{in} \mathrm{a} \mathrm{patient} \mathrm{with}$ confirmed coronavirus disease 2019 under spinal anaesthesia. $\mathrm{Br} J$ Anaesth 2020.

Publisher Full Text 
31. Wang S, Guo L, Chen L, et al.: A Case Report of Neonatal 2019 Coronavirus Disease in China. Clin Infect Dis. 2020.

Publisher Full Text

32. Zeng L, Xia S, Yuan W, et al.: Neonatal Early-Onset Infection With SARS-CoV-2 in 33 Neonates Born to Mothers With COVID-19 in Wuhan, China. JAMA Pediatr. 2020 .

PubMed Abstract | Publisher Full Text | Free Full Text

33. Dong L, Tian J, He S, et al:: Possible Vertical Transmission of SARS-CoV-2 From an Infected Mother to Her Newborn. JAMA. 2020.

PubMed Abstract | Publisher Full Text | Free Full Text

34. Díaz CA, Maestro ML, Pumarega MTM, et al:: [First case of neonatal infection due to COVID 19 in Spain]. An Pediatr (Barc). 2020; pii: S1695-4033(20)30130-2. PubMed Abstract | Publisher Full Text

35. Kalafat E, Yaprak E, Cinar G, et al.: Lung ultrasound and computed tomographic findings in pregnant woman with COVID-19. Ultrasound Obstet Gynecol. 2020. PubMed Abstract | Publisher Full Text

36. Lee DH, Lee J, Kim E, et al:: Emergency cesarean section on severe acute respiratory syndrome coronavirus 2 (SARS- CoV-2) confirmed patient. Korean J Anesthesiol. 2020.

PubMed Abstract | Publisher Full Text

37. Gidlöf S, Savchenko J, Brune T, et al.: CovID-19 in pregnancy with comorbidities: More liberal testing strategy is needed. Acta Obstet Gynecol Scand. 2020.

PubMed Abstract | Publisher Full Text

38. Zambrano LI, Fuentes-Barahona IC, Bejarano-Torres DA, et al:: A pregnant woman with COVID-19 in Central America. Travel Med Infect Dis. 2020; 101639. PubMed Abstract | Publisher Full Text

39. Zhang $\mathrm{L}$, Jiang $\mathrm{Y}$, Wei $\mathrm{M}$, et al: [Analysis of the pregnancy outcomes in pregnant women with COVID-19 in Hubei Province]. Zhonghua Fu Chan Ke Za Zhi. 2020; 55(0): E009.

PubMed Abstract | Publisher Full Text

40. Li N, Han L, Peng M, et al:: Maternal and neonatal outcomes of pregnant women with COVID-19 pneumonia: a case-control study. Clin Infect Dis. 2020; pii: ciaa352.

PubMed Abstract | Publisher Full Text | Free Full Text

41. Zaigham M, Andersson O: Maternal and Perinatal Outcomes with COVID-19: a systematic review of 108 pregnancies. Acta Obstet Gynecol Scand. 2020. PubMed Abstract | Publisher Full Text

42. Wen R, Sun $Y$, Xing QS: A patient with SARS-CoV-2 infection during pregnancy in Qingdao, China. J Microbiol Immunol Infect. 2020; pii: S1684-1182(20)30061-X. PubMed Abstract | Publisher Full Text | Free Full Text

43. Moro F, Buonsenso D, Moruzzi MC, et al.: How to perform lung ultrasound in pregnant women with suspected COVID-19. Ultrasound Obstet Gynecol. 2020; 55(5): 593-598.

PubMed Abstract | Publisher Full Text

44. Liu H, Liu F, Li J, et al.: Clinical and CT imaging features of the COVID-19 pneumonia: Focus on pregnant women and children. $J$ Infect. 2020; 80(5): e7-e13.

PubMed Abstract | Publisher Full Text | Free Full Text

45. Zheng QL, Duan T, Jin LP: Single-cell RNA expression profiling of ACE2 and AXL in the human maternal-Fetal interface. Reprod Dev Med. 2020; 4(1): 7-10. Publisher Full Text

46. Levy A, Yagil Y, Bursztyn M, et al:: ACE2 expression and activity are enhanced during pregnancy. Am J Physiol Integr Comp Physiol. 2008; 295(6): R1953-R1961. PubMed Abstract | Publisher Full Text

47. Delforce SJ, Lumbers ER, Ellery SJ, et al:: Dysregulation of the placental renin-angiotensin system in human fetal growth restriction. Reproduction. 2019; 158(3): 237-245

PubMed Abstract | Publisher Full Text

48. Ghadhanfar E, Alsalem A, Al-Kandari S, et al.: The role of ACE2, angiotensin(1-7) and Mas1 receptor axis in glucocorticoid-induced intrauterine growth restriction. Reprod Biol Endocrinol. 2017; 15(1): 97.

PubMed Abstract | Publisher Full Text | Free Full Text

49. World Health Organization: Report of the WHO-China Joint Mission on Coronavirus Disease 2019 (COVID-19). 2020

Reference Source

50. Mullins E, Evans D, Viner RM, et al:: Coronavirus in pregnancy and delivery: rapid review. Ultrasound Obstet Gynecol. 2020; uog.22014.

Publisher Full Text

51. Panahi L, Amiri M, Pouy S: Risks of Novel Coronavirus Disease (COVID-19) in Pregnancy; a Narrative Review. Arch Acad Emerg Med. 2020; 8(1): e34. PubMed Abstract | Free Full Text

52. Dashraath P, Wong JLJ, Lim MXK, et al:: Coronavirus disease 2019 (COVID-19) pandemic and pregnancy. Am J Obstet Gynecol. 2020; pii: S0002-9378(20)30343-4. PubMed Abstract | Publisher Full Text

53. Chen YH, Keller J, Wang IT, et al.: Pneumonia and pregnancy outcomes: a nationwide population-based study. Am J Obstet Gynecol. 2012; 207(4): 288. e1-288.e7.

PubMed Abstract | Publisher Full Text | Free Full Text

54. Zhong NS, Zheng BJ, Li YM, et al.: Epidemiology and cause of severe acute respiratory syndrome (SARS) in Guangdong, People's Republic of China, in February, 2003. Lancet. 2003; 362(9393): 1353-8. PubMed Abstract | Publisher Full Text | Free Full Text
55. World Health Organization (Department of Communicable Disease Surveillance and Response): Consensus document on the epidemiology of severe acute respiratory syndrome (SARS). 2003.

Reference Source

56. Shek CC, Ng PC, Fung GP, et al:: Infants born to mothers with severe acute respiratory syndrome. Pediatrics. 2003; 112(4): e254-e254.

PubMed Abstract | Publisher Full Text

57. Stockman LJ, Lowther SA, Coy K, et al.: SARS during pregnancy, United States. Emerg Infect Dis. 2004; 10(9): 1689-90.

PubMed Abstract | Publisher Full Text | Free Full Text

58. Lam CM, Wong SF, Leung TN, et al: A case-controlled study comparing clinical course and outcomes of pregnant and non-pregnant women with severe acute respiratory syndrome. BJOG. 2004; 111(8): 771-774.

PubMed Abstract | Publisher Full Text | Free Full Text

59. Ng WF, Wong SF, Lam A, et al:: The placentas of patients with severe acute respiratory syndrome: a pathophysiological evaluation. Pathology. 2006; 38(3): 210-218.

PubMed Abstract | Publisher Full Text | Free Full Text

60. Maxwell C, Mcgeer A, Fan K, et al.: SOGC CLINICAL PRACTICE GUIDELINE No. 225-Management Guidelines for Obstetric Patients and Neonates Born to Mothers With Suspected or Probable Severe Acute Respiratory Syndrome (SARS). J Obs Gynaecol Can. 2017; 39(8): e130-e137. Publisher Full Text

61. Zaki AM, van Boheemen S, Bestebroer TM, et al:: Isolation of a novel coronavirus from a man with pneumonia in Saudi Arabia. N Engl J Med. 2012; 367(19): $1814-1820$.

PubMed Abstract | Publisher Full Text

62. Assiri A, Abedi GR, Al Masri M, et al.: Middle East Respiratory Syndrome Coronavirus Infection During Pregnancy: A Report of 5 Cases From Saudi Arabia. Clin Infect Dis. 2016; 63(7): 951-953. PubMed Abstract | Publisher Full Text | Free Full Text

63. Payne DC, Iblan I, Alqasrawi S, et al.: Stillbirth during infection with Middle East respiratory syndrome coronavirus. J Infect Dis. 2014; 209(12): 1870-1872. PubMed Abstract | Publisher Full Text | Free Full Text

64. Alserehi H, Wali G, Alshukairi A, et al:: Impact of Middle East Respiratory Syndrome coronavirus (MERS CoV) on pregnancy and perinatal outcome. BMC Infect Dis. 2016; 16: 105.

PubMed Abstract | Publisher Full Text | Free Full Text

65. Malik A, El Masry KM, Ravi M, et al.: Middle East Respiratory Syndrome Coronavirus during Pregnancy, Abu Dhabi, United Arab Emirates, 2013. Emerg Infect Dis. 2016; 22(3): 515-517.

PubMed Abstract | Publisher Full Text | Free Full Text

66. Alfaraj SH, Al-Tawfiq JA, Memish ZA: Middle East Respiratory Syndrome Coronavirus (MERS-CoV) infection during pregnancy: Report of two cases and review of the literature. J Microbiol Immunol Infect. 2019; 52(3): 501-503. PubMed Abstract | Publisher Full Text | Free Full Text

67. Jeong SY, Sung SI, Sung JH, et al.: MERS-CoV Infection in a Pregnant Woman in Korea. J Korean Med Sci. 2017; 32(10): 1717-1720. PubMed Abstract | Publisher Full Text | Free Full Text

68. Fehr AR, Perlman S: Coronaviruses: an overview of their replication and pathogenesis. Methods Mol Biol. 2015; 1282: 1-23. PubMed Abstract | Publisher Full Text | Free Full Text

69. Gagneur A, Dirson E, Audebert S, et al:: Materno-fetal transmission of human coronaviruses: a prospective pilot study. Eur J Clin Microbiol Infect Dis. 2008; 27(9): 863-866.

PubMed Abstract | Publisher Full Text | Free Full Text

70. Schwartz DA, Graham AL: Potential Maternal and Infant Outcomes from Coronavirus 2019-nCoV (SARS-CoV-2) Infecting Pregnant Women: Lessons from SARS, MERS, and Other Human Coronavirus Infections. Viruses. 2020; 12(2): 194.

PubMed Abstract | Publisher Full Text | Free Full Text

71. Mertz D, Kim TH, Johnstone J, et al:: Populations at risk for severe or complicated influenza illness: systematic review and meta-analysis. $B M$ 2013; 347: f5061-f5061.

PubMed Abstract | Publisher Full Text | Free Full Text

72. Gottfredsson M: The Spanish flu in Iceland 1918. Lessons in medicine and history. Laeknabladid. 2008; 94(11): 737-45.

Reference Source

73. Siston AM, Rasmussen SA, Honein MA, et al.: Pandemic 2009 Influenza A(H1N1) Virus Illness Among Pregnant Women in the United States. JAMA. 2010; 303(15): 1517

PubMed Abstract | Publisher Full Text | Free Full Text

74. Jamieson D, Theiler R, Rasmussen S: Emerging infections and pregnancy. Emerg Infect Dis. 2006; 12(11): 1638-1643.

PubMed Abstract | Publisher Full Text | Free Full Text

75. Littauer EQ, Skountzou I: Hormonal Regulation of Physiology, Innate Immunity and Antibody Response to H1N1 Influenza Virus Infection During Pregnancy. Front Immunol. 2018; 9: 2455.

PubMed Abstract | Publisher Full Text | Free Full Text

76. World Health Organization: Vaccines against Influenza WHO Position Paper - November 2012. 2012.

Reference Source

77. Mertz D, Lo CKF, Lytvyn L, et al.: FLURISK-INVESTIGATORS. Pregnancy as a 
risk factor for severe influenza infection: an individual participant data meta-analysis. BMC Infect Dis. 2019; 19(1): 683.

PubMed Abstract | Publisher Full Text | Free Full Text

78. Laake I, Tunheim G, Robertson AH, et al.: Risk of pregnancy complications and adverse birth outcomes after maternal $A(H 1 N 1)$ pdm09 influenza: a Norwegian population-based cohort study. BMC Infect Dis. 2018; 18(1): 525. PubMed Abstract | Publisher Full Text | Free Full Text

79. Ribeiro AF, Pellini ACG, Kitagawa BY, et al.: Severe influenza A(H1N1)pdm09 in pregnant women and neonatal outcomes, State of Sao Paulo, Brazil, 2009. PLoS One. 2018; 13(3): e0194392.

PubMed Abstract | Publisher Full Text | Free Full Text

80. Newsome $\mathrm{K}$, Alverson $\mathrm{CJ}$, Williams $\mathrm{J}$, et al: Outcomes of infants born to women with influenza A(H1N1)pdm09. Birth Defects Res. 2019; 111(2): 88-95. PubMed Abstract | Publisher Full Text | Free Full Text

81. Fell D, Savitz D, Kramer M, et al.: Maternal influenza and birth outcomes: systematic review of comparative studies. BJOG. 2017; 124(1): 48-59. PubMed Abstract | Publisher Full Text | Free Full Text

82. Littauer $E Q$, Esser $E S$, Antao $O Q$, et al:: H1N1 influenza virus infection results in adverse pregnancy outcomes by disrupting tissue-specific hormonal regulation. PLoS Pathog. 2017; 13(11): e1006757. PubMed Abstract | Publisher Full Text | Free Full Text

83. Luteijn JM, Brown MJ, Dolk H: Influenza and congenital anomalies: a systematic review and meta-analysis. Hum Reprod. 2014; 29(4): 809-823. PubMed Abstract | Publisher Full Tex

84. Blomström Å, Karlsson H, Gardner R, et al:: Associations Between Maternal Infection During Pregnancy, Childhood Infections and the Risk of Subsequen Psychotic Disorder-A Swedish Cohort Study of Nearly 2 Million Individuals. Schizophr Bull. 2015; 42(1): sbv112.

PubMed Abstract | Publisher Full Text | Free Full Text

85. Cai L, Wan CL, He L, et al:: Gestational Influenza Increases the Risk of Psychosis in Adults. Med Chem. 2015; 11(7): 676-682. PubMed Abstract | Publisher Full Text

86. Selten JP, Termorshuizen F: The serological evidence for maternal influenza as risk factor for psychosis in offspring is insufficient: critical review and meta-analysis. Schizophr Res. 2017; 183: 2-9. PubMed Abstract | Publisher Full Text

87. Creanga A: Transplacental transmission of influenza virus: What do we know? Indian J Med Sci. 2010; 64(12): 529.

PubMed Abstract | Publisher Full Text

88. Fell DB, Bhutta ZA, Hutcheon JA, et al:: Report of the WHO technica consultation on the effect of maternal influenza and influenza vaccination on the developing fetus: Montreal, Canada, September 30-October 1, 2015. Vaccine. 2017; 35(18): 2279-2287. PubMed Abstract | Publisher Full Text

89. Yang $\mathrm{H}$, Wang $\mathrm{C}$, Poon LC: Novel coronavirus infection and pregnancy. Ultrasound Obstet Gynecol. 2020; 55(4): 435-437. PubMed Abstract | Publisher Full Text | Free Full Text

90. Favre G, Pomar L, Musso D, et al:: 2019-nCoV epidemic: what about pregnancies? Lancet. 2020; 395(10224): e40. PubMed Abstract | Publisher Full Text | Free Full Text

91. World Health Organization: Clinical Management of Severe Acute Respiratory Infection When COVID-19 Is Suspected. Interim Guidance. 2020. Reference Source

92. Poon LC, Yang H, Lee JC, et al.: ISUOG Interim Guidance on $\mathbf{2 0 1 9}$ novel coronavirus infection during pregnancy and puerperium: information for healthcare professionals. Ultrasound Obstet Gynecol. 2020; 55(5): 700-708. PubMed Abstract | Publisher Full Text

93. Peyronnet V, Sibiude J, Deruelle P, et al: SARS-CoV-2 infection during pregnancy. Information and proposal of management care. CNGOF. Gynecol Obstet Fertil Senol. 2020; 48(5): 436-443.

PubMed Abstract | Publisher Full Text | Free Full Text

94. Chawla D, Chirla D, Dalwai S: Perinatal-Neonatal Management of COVID-19 Infection - Guidelines of the Federation of Obstetric and Gynecological Societies of India (FOGSI), National Neonatology Forum of India (NNF), and Indian Academy of Pediatrics (IAP). Indian Pediatr. 2020. pii: S097475591600154. PubMed Abstract

95. Davanzo $R$, Moro $G$, Sandri $F$, et al: Breastfeeding and coronavirus disease2019: Ad interim indications of the Italian Society of Neonatology endorsed by the Union of European Neonatal \& Perinatal Societies. Matern Child Nutr. 2020; e13010.

PubMed Abstract | Publisher Full Text

96. Poon LC, Yang $\mathrm{H}$, Kapur A: Global interim guidance on coronavirus disease 2019 (COVID-19) during pregnancy and puerperium from FIGO and allied partners: Information for healthcare professionals. Int J Gynecol Obstet. 2020. PubMed Abstract | Publisher Full Text

97. Chen $\mathrm{D}, \mathrm{Yang} \mathrm{H}, \mathrm{CaO} \mathrm{Y}$ : Expert consensus for managing pregnant women and neonates born to mothers with suspected or confirmed novel coronavirus (COVID-19) infection. Int J Gynecol Obstet. 2020; 149(2): 130-136. PubMed Abstract | Publisher Full Text

98. Qiao J: What are the risks of COVID-19 infection in pregnant women? Lancet 2020; 395(10226): 760-762.

PubMed Abstract | Publisher Full Text | Free Full Tex

99. Favre G, Pomar L, Qi X, et al.: Guidelines for pregnant women with suspected SARS-CoV-2 infection. Lancet Infect Dis. 2020; pii: S1473-3099(20)30157-2. PubMed Abstract | Publisher Full Text | Free Full Text

100. Schmid MB, Fontijn J, Ochsenbein-Kölble N, et al:: COVID-19 in pregnant women. Lancet Infect Dis. 2020; pii: S1473-3099(20)30175-4. PubMed Abstract | Publisher Full Text

101. Wang S, Zhou X, Lin X, et al:: Experience of Clinical Management for Pregnan Women and Newborns with Novel Coronavirus Pneumonia in Tongji Hospital, China. Curr Med Sci. 2020; 40(2): 285-289. PubMed Abstract | Publisher Full Text

102. Rimmer A: Covid-19: doctors in final trimester of pregnancy should avoid direct patient contact. BMJ. 2020; 368: $\mathrm{m} 1173$. PubMed Abstract | Publisher Full Text

103. Tang N, Li D, Wang X, et al:: Abnormal coagulation parameters are associated with poor prognosis in patients with novel coronavirus pneumonia. $J$ Thromb Haemost. 2020; 18(4): 844-847. PubMed Abstract | Publisher Full Text | Free Full Text

104. Erez O, Mastrolia SA, Thachil J: Disseminated intravascular coagulation in pregnancy: insights in pathophysiology, diagnosis and management. $A m \mathrm{~J}$ Obstet Gynecol. 2015; 213(4): 452-463. PubMed Abstract | Publisher Full Text

105. Ai T, Yang Z, Hou H, et al.: Correlation of Chest CT and RT-PCR Testing in Coronavirus Disease 2019 (COVID-19) in China: A Report of 1014 Cases. Radiology. 2020; 200642 PubMed Abstract | Publisher Full Text

106. Capanna F, Haydar A, McCarey C, et al:: Preparing an obstetric unit in the heart of the epidemic strike of COVID-19: quick reorganization tips. J Matern Fetal Neonatal Med. 2020; 1-7. PubMed Abstract | Publisher Full Text

107. Poon LC, Abramowicz JS, Asta AD, et al:: ISUOG Safety Committee Position Statement: safe performance of obstetric and gynecological scans and equipment cleaning in the context of COVID-19. Ultrasound Obstet Gynecol. 2020; 55(5): 709-712. PubMed Abstract | Publisher Full Text

108. Gao J, Tian Z, Yang X: Breakthrough: Chloroquine phosphate has shown apparent efficacy in treatment of COVID-19 associated pneumonia in clinical studies. Biosci Trends. 2020; 14(1): 72-73. PubMed Abstract | Publisher Full Text

109. Karunajeewa HA, Salman S, Mueller I, et al:: Pharmacokinetics of Chloroquine and Monodesethylchloroquine in Pregnancy. Antimicrob Agents Chemother. 2010; 54(3): 1186-1192. PubMed Abstract | Publisher Full Text | Free Full Text

110. Zhou D, Dai SM, Tong Q: COVID-19: a recommendation to examine the effect of hydroxychloroquine in preventing infection and progression. $J$ Antimicrob Chemother. 2020; pii: dkaa114. PubMed Abstract | Publisher Full Text | Free Full Text

111. Schwartz DA, Graham AL: Potential Maternal and Infant Outcomes from Coronavirus 2019-nCoV (SARS-CoV-2) Infecting Pregnant Women: Lessons from SARS, MERS, and Other Human Coronavirus Infections. Viruses. 2020; 12(2): pii: E194. PubMed Abstract | Publisher Full Text | Free Full Text

112. Alder J, Fink N, Bitzer J, et al:: Depression and anxiety during pregnancy: A risk factor for obstetric, fetal and neonatal outcome? A critical review of the literature. J Matern Fetal Neonatal Med. 2007; 20(3): 189-209. PubMed Abstract | Publisher Full Text

113. Littleton $\mathrm{HL}$, Breitkopf $\mathrm{CR}$, Berenson $\mathrm{AB}$ : Correlates of anxiety symptoms during pregnancy and association with perinatal outcomes: a meta-analysis. $A m$ Obstet Gynecol. 2007; 196(5): 424-432. PubMed Abstract | Publisher Full Text

114. $\mathrm{Ng}$ J, Sham A, Tang PL, et al.: SARS: pregnant women's fears and perceptions. Br J Midwifery. 2004; 12(11): 698-702. Publisher Full Text

115. Gregg VH, Ferguson JE: Exercise in Pregnancy. Clin Sports Med. 2017; 36(4): $741-752$ PubMed Abstract | Publisher Full Text

116. World Health Organization: Trends in maternal mortality 2000 to 2017 : estimates by WHO, UNICEF, UNFPA, World Bank Group and the United Nations Population Division: executive summary. 2019.

Reference Source 


\section{Open Peer Review}

\section{Current Peer Review Status:}

\section{Version 1}

Reviewer Report 22 February 2021

https://doi.org/10.5256/f1000research.25980.r79428

C 2021 Montagnoli C. This is an open access peer review report distributed under the terms of the Creative Commons Attribution License, which permits unrestricted use, distribution, and reproduction in any medium, provided the original work is properly cited.

\section{Caterina Montagnoli}

Department of Midwifery, Geneva School of Health Sciences, HES-SO University of Applied Sciences and Arts of Western Switzerland, Geneva, Switzerland

I congratulate the authors for the extensive work on the review on COVID-19 effects upon pregnancy and maternal and neonatal outcomes.

I have few but essential comments for improving the text.

In the abstract: "a clinical presentation of the disease" is used. Please rephrase this sentence to make it more accessible.

Why describing the impact of other viral respiratory infections? Please add a sentence to justify your choice beside the lack of COVID-19 knowledge also in this part of the text.

This insight on other coronaviruses and pregnancy is very interesting. Nevertheless, it adds little information about the management of the current COVID-19 disease.

Were letters, perspectives, and reviews included in your data extraction/shortlisted papers?

You write: "The results of a point-of-care lung-ultrasound examination were found to correlate with CT findings in one pregnant women; and therefore, this technique has been proposed as a tool to facilitate the triage of mothers with suspected COVID-19" but were the articles case reports or studies? Were there statistical analysis?

In the conclusions you could discuss more recent literature and evidence regarding the administration of vaccines to pregnant women.

I also advice an update with more recent case studies and other databases for the search.

Is the topic of the review discussed comprehensively in the context of the current 


\section{literature?}

Partly

\section{Are all factual statements correct and adequately supported by citations?}

Yes

Is the review written in accessible language?

Partly

Are the conclusions drawn appropriate in the context of the current research literature? Partly

Competing Interests: No competing interests were disclosed.

Reviewer Expertise: Midwifery, Obstetrics, education, simulation

I confirm that I have read this submission and believe that I have an appropriate level of expertise to confirm that it is of an acceptable scientific standard, however I have significant reservations, as outlined above.

Reviewer Report 10 August 2020

\section{https://doi.org/10.5256/f1000research.25980.r68159}

(c) 2020 Rodriguez-Morales A. This is an open access peer review report distributed under the terms of the Creative Commons Attribution License, which permits unrestricted use, distribution, and reproduction in any medium, provided the original work is properly cited.

\section{Alfonso J. Rodriguez-Morales}

Faculty of Health Sciences, Universidad Tecnológica de Pereira, Pereira, Colombia

This a very interesting review, addressing a relevant topic in the context of the coronavirus disease 2019 (COVID-19), its impact on pregnancy. Although I congratulate the authors for the efforts, before can be fully acceptable it deserves some improvements, including an update of the review. This review is based on two searches in the literature in two databases. The last review on April 8, 2020. Then, this means, more than four months have passed. For COVID-19 this is a lot. Multiple case reports, studies, and even reviews, and systematic reviews have came out. Then, this needs to be updated, including other additional databases, such as Scopus, and Web of Sciences. The section of Mother-to-Child transmission should be reviewed carefully, as new evidence suggested, that although sporadically, some cases ended in vertical transmission.

Finally, I would suggest to extend more the Conclusions, specially to better discuss the current and future implications of the COVID-19 on pregnancy.

Is the topic of the review discussed comprehensively in the context of the current literature? 
Partly

Are all factual statements correct and adequately supported by citations? Partly

Is the review written in accessible language?

Yes

Are the conclusions drawn appropriate in the context of the current research literature? Partly

Competing Interests: No competing interests were disclosed.

Reviewer Expertise: I am a Senior Researcher in Tropical and Emerging Infectious Diseases, currently Chair of the Latin American Network of Coronavirus Disease 2019 (COVID-19) Research (LANCOVID), http://www.lancovid.org/.

I confirm that I have read this submission and believe that I have an appropriate level of expertise to confirm that it is of an acceptable scientific standard.

The benefits of publishing with F1000Research:

- Your article is published within days, with no editorial bias

- You can publish traditional articles, null/negative results, case reports, data notes and more

- The peer review process is transparent and collaborative

- Your article is indexed in PubMed after passing peer review

- Dedicated customer support at every stage

For pre-submission enquiries, contact research@f1000.com

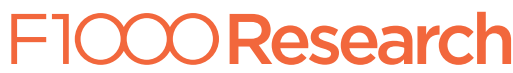

